\title{
ОСНОВНЫЕ НАПРАВЛЕНИЯ СОВЕРШЕНСТВОВАНИЯ КОРМОПРОИЗВОДСТВА
}

\author{
Д.Г. Гвазава (фото) \\ д.э.Н., к.С.-Х.Н., директор \\ Л.А. Хомутова \\ к.э.н., ведущий научный сотрудник отдела экономики \\ и бухгалтерского учёта \\ Л.М. Исаева \\ старший научный сотрудник отдела экономики \\ и бухгалтерского учёта \\ ФГБНУ «Костромской научно-исследовательский институт \\ сельского хозяйства», с. Минское
}

Костромская область расположена в центре Нечернозёмной зоны

Кормопроизводство, качество, урожсайность, разнокачественные культуры, зонирование территории, рациональное размещение, молочное скотоводство

Fodder production, quality, crop productivity, heterogeneous crops, territorial zoning, rational distribution, dairy farming
Европейской части Российской Федерации, её территория составляет 60,2 тыс. Кв. Км, население - 637 тыс. чел., плотность населения - 10,8 чел. на 1 кв. км, соотношение городского и сельского населения - 72\% к $28 \%$.

Молочное скотоводство является ведущей подотраслью животноводства и его развитие имеет существенное значение не только в самообеспеченности Костромской области молоком и молочными продуктами, но и в социальном аспекте. Нашими исследованиями установлено, что население области потребляет молока и молочных продуктов в количестве 198 кг, что на $39 \%$ меньше рекомендуемой нормы (325 кг в год на человека). Произведённый в регионе объём молока может удовлетворить потребности населения лишь на 52\%, а для полного обеспечения требуется увеличение его производства на 130 тыс. т в год, или в 2,6 раза [1].

Успешное развитие молочной подотрасли в значительной степени зависит от роста продуктивности коров, оптимизации их воспроизводительных качеств и состояния здоровья, увеличения поголовья молочного скотоводства, совершенствования кормопроизводства и организации полноценного кормления животных. Обеспечение молочного скотоводства кормами в необходимом количестве и качестве базируется на полевом кормопроизводстве, удовлетворяющем потребности в концентрированных и объёмистых кормах, которое будет определяться новыми сортами, адаптированными к зональному размещению, технологиями возделывания сельскохозяйственных культур, организацией интенсивной системы кормопроизводства и эффективным использованием кормовых ресурсов [2].

Костромская область располагает значительным земельным ресурсом для обеспечения молочного скотоводства кормами. В сельскохозяйственных организациях области общая земельная площадь в 2018 г. составляла 200,9 тыс. га. По сравнению с 2014 г. уменьшилась 
на 49 тыс. га, или на 19,6\%. Площадь сельскохозяйственных угодий не превышает 165,9 тыс. га, в том числе используется организациями $94 \%$. В структуре сельскохозяйственных угодий на долю пашни приходится 86\% (142,8 тыс. га), сенокосов $6 \%$ (9,8 тыс. га) и пастбищ $8 \%$ (12,8 тыс. га). Показатели уровня использования пашни в производстве свидетельствуют о весьма негативной динамике. В 2018 г. вся посевная площадь составляла 131,3 тыс. га. Она сократилась на 19,4 тыс. га, или на 12,9\%, по сравнению с 2014 г. В структуре посевных площадей многолетние травы занимали $69 \%$, зерновые культуры - 20,6, однолетние травы - 8,1, картофель - 0,7 , овощи открытого грунта $-0,1 \%$.

Показатели производства однолетних и многолетних трав в сельскохозяйственных организациях Костромской области в 2014-2018 гг. представлены в таблице 1.

Из таблицы 1 видно, что за анализируемый период площадь кормовых культур сократились на 10,1 тыс. га, или на 9\%. В структуре кормовых культур на долю многолетних трав приходилось 88,9 , однолетних трав - 10,4, прочих культур $0,7 \%$. За этот период урожайность зелёной массы однолетних и многолетних трав, а также сена увеличилась на 42,1, 2,4 и 0,9 ц/га, или на 68,5, 8,4 и $5,5 \%$ соответственно. Валовой сбор зелёной массы и объём закладки силоса увеличились на 34,8 и 38,1 тыс. т, или на 9,7 и 23,9\% соответственно. В 2018 г. по сравнению с 2014 г. было меньше заготовлено сена и сенажа на 9,3 и 9,2 тыс. т, или на 18,1 и $21,1 \%$ соответственно. Низкая урожайность зелёной массы обусловлена несколькими причинами: отсутствием кормового севооборота с набором бобовых и бобово-злаковых травосмесей, старо-возрастным травостоем (более $60 \%$ посевов клевера лугового 3-го и более годов пользования) [3], отсутствием системы семеноводства; минеральные удобрения вносятся на 18-19\% общей площади кормовых культур в дозах, не превышающих 11-12 кг/га действующего вещества.

Вследствие низкой продуктивности и незначительного удельного веса в структуре посевных площадей бобовых культур крайне низким остаётся качество объёмистых и концентрированных кормов. Довольно низка доля высококлассных заготовляемых кормов: так, в 2018 г. проверку качества прошли 19\% сена, 31\% сенажа и 39\% силоса. Проверка показала следующие результаты: сено I класса - 46\%, II класса - 19\%, III класса - $2 \%$ и неклассное - $33 \%$; сенаж I класса $52 \%$ и II класса - 48\%; силос I класса - 24\%, II класса $-64 \%$, III класса - 8\% и неклассный - 4\%. Технологии заготовки и хранения кормов не отвечают

Таблица 1 - Показатели производства однолетних и многолетних трав в сельскохозяйственных организациях Костромской области (2014-2018 гг.)

\begin{tabular}{|l|c|c|c|c|c|}
\hline \multicolumn{2}{|c|}{ Показатель } & \multicolumn{3}{c|}{ Год } \\
\cline { 2 - 5 } & 2014 & 2015 & 2016 & 2017 & 2018 \\
\hline Площадь кормовых культур всего, тыс. га & 112,4 & 116,2 & 111,2 & 111,1 & 102,3 \\
\hline в том числе: - однолетние травы & 11,7 & 14,8 & 13,3 & 13,6 & 10,6 \\
\hline \multicolumn{1}{|c|}{ - многолетние травы } & 99,5 & 100,0 & 97,0 & 97,2 & 90,9 \\
\hline - прочие & 1,2 & 1,4 & 0,9 & 0,3 & 0,8 \\
\hline Урожайность зелёной массы однолетних трав, ц/га & 61,5 & 64,2 & 54,5 & 72,7 & 103,6 \\
\hline Урожайность зелёной массы многолетних трав, ц/га & 28,7 & 29,8 & 32,9 & 35,6 & 31,1 \\
\hline Валовой сбор зелёной массы, тыс. т & 357,8 & 392,8 & 391,7 & 428,9 & 392,6 \\
\hline Себестоимость зелёной массы, руб./ц & 40,0 & 41,1 & 40,9 & 53,7 & 43,3 \\
\hline Урожайность сена, ц/га & 16,5 & 19,1 & 15,9 & 19,2 & 17,4 \\
\hline Валовой сбор сена, тыс. т & 51,4 & 58,4 & 50,4 & 55,2 & 42,1 \\
\hline Себестоимость сена, руб./ц & 137,9 & 119,6 & 123,5 & 123,7 & 134,4 \\
\hline Производство силоса, тыс. т & 159,5 & 203,0 & 181,6 & 209,3 & 197,6 \\
\hline Себестоимость силоса, руб./ц & 75,6 & 89,5 & 84,3 & 100,0 & 93,2 \\
\hline Производство сенажа, тыс. т & 43,6 & 28,8 & 27,9 & 37,4 & 34,4 \\
\hline Себестоимость сенажа, руб./ц & 133,5 & 112,7 & 100,4 & 124,0 & 124,7 \\
\hline
\end{tabular}


современным требованиям, позволяющим обеспечить животных сбалансированными рационами кормления, что приводит к необоснованному завышению себестоимости кормов. Из-за низкой их поедаемости, а также отсутствия средств для приобретения высокоэнергетических кормов, коровы не могут проявить свой генетический потенциал, а предприятия, в свою очередь, обеспечить производство конкурентоспособной продукцией $[2,4]$. Недостаточным является обеспечение отрасли кормоуборочной техникой. За период с 2014 по 2018 гг. количество кормоуборочных и кормозаготовительных комбайнов сократилось на 8 единиц, их число в расчёте на 1000 га кормовых культур составило 1,3 ед.

Таким образом, отрасль кормопроизводства в Костромской области характеризуется низкими производственными показателями. Вместе с тем, в регионе имеются внутренние резервы для внедрения технологий выращивания кормовых культур, заготовки и хранения кормов для обеспечения увеличения объёмов продукции молочного скотоводства, что будет способствовать росту эффективности производства и его конкурентоспособности.

Совершенствование подотрасли кормопроизводства в регионе предусматривает:

1. Формирование региональной кормовой базы должно сочетаться со сложившейся или рекомендуемой для конкретных условий системы ведения животноводства, в том числе молочного скотоводства. Это связано с определением основных природно-экономических зон производства молока и говядины, производственной специализацией отрасли, концентрацией поголовья, использованием высокопродуктивных адаптированных пород крупного рогатого скота, наличием и состоянием кормовыхугодий, обеспеченностью материально-техническими, кормовыми и трудовыми ресурсами, финансовыми возможностями. Переход на узкоспециализированную систему производства сельскохозяйственной продукции направлен на более эффективное использование почвенно-климатических особенностей, материально-технических и трудовых ресурсов.

2. Осуществление зонирования всей территории региона для обеспечения высокоэффективного аграрного производства. Это особенно актуально для Костромской области в силу её географического расположения и природно-климатических условий. Например, десять близлежащих к областному центру районов могут быть отнесены к зоне разведения молочного ското- водства, так как крупные молокоперерабатывающие предприятия находятся в областном центре. В этой зоне можно сосредоточить не менее 73-75 тыс. голов коров в крупных животноводческих предприятиях с поголовьем не менее 1,5-2,5 тыс. коров в каждом. Эту же зону можно рассматривать для производства овощей открытого грунта и частично картофеля. В других четырнадцати отдалённых районах северо-востока, которые расположены от областного центра на расстоянии 300-600 км, можно успешно развивать мясное скотоводство, овцеводство, козоводство, свиноводство, производство зерновых культур, масличного льна, картофеля, перерабатывающие предприятия.

3. Совершенствование структуры посевных площадей кормовых и зернофуражных культур за счёт рационального размещения их в системе севооборотов и расширения видового и сортового разнообразия с учётом агроландшафтно-экологического районирования и физиологических потребностей сельскохозяйственных животных. Это создаст возможность для повышения устойчивости кормопроизводства независимо от погодных условий за счёт компенсационных возможностей биологически разнокачественных культур.

4. Повышение качества производимых кормов за счёт увеличения доли бобовых трав и бобово-злаковых травосмесей в структуре площадей многолетних трав и расширения посевов зернобобовых (горох, вика, люпин узколистный, соя) в одновидовых посевах и в смеси с ячменём и овсом на зернофураж, а также использования более эффективных видов и многообразия сортов северного экотипа многолетних бобовых трав (козлятник восточный, лядвенец рогатый). Производство кормовых культур с высокими показателями питательности кормов позволит добиться снижения общего расхода кормов на производство тех же объёмов скотоводческой продукции, чем при использовании некачественных кормов. Нашими исследованиями установлено, что кормление коров низкокачественными кормами в конечном итоге приводит к удорожанию стоимости суточного рациона и увеличению затрат кормов на производство единицы продукции на 15,0-15,5\%. С экономической точки зрения качество корма оказывает значительное влияние на себестоимость и рентабельность животноводческой продукции. Расчётами установлено, что эффективность кормопроизводства можно обеспечить при урожайности кормовых культур не менее 200-210 ц/га с одновременным соблю- 
дением технологии заготовки и хранения кормов. Считаем, что для повышения эффективности кормопроизводства оно должно быть выделено отдельной отраслью.

5. Переход на узкоспециализированную систему производства сельскохозяйственной продукции автоматически потребует внедрения иных методов организации, планирования и управления производственными процессами, которые в конечном итоге приведут к существенному сокращению накладных расходов, и, кроме того, средств на амортизацию вследствие применения специфичных для отрасли технических средств.
Осуществление комплексных мероприятий по совершенствованию отрасли кормопроизводства обеспечит организацию высокоэффективного производства продукции молочного и мясного скотоводства с целью удовлетворения населения продуктами питания собственного производства, решение проблемы импортозамещения, широкомасштабного вовлечения невостребованных сельскохозяйственных угодий и увеличения благосостояния работников в аграрной сфере. Считаем, что у Костромской области имеется перспектива стать динамично развивающимся регионом по производству продукции молочного скотоводства.

\section{תumepamypa}

1. Гвазава, Д.Г. Направления повышения эффективности молочного скотоводства в Костромской области [Текст] / Д.Г. Гвазава, Л.А. Хомутова, Л.М. Исаева // Современные наукоемкие технологии. Региональное приложение. - 2018. - № 2 (54). - С. 102-112.

2. Гвазава, Д.Г. Эффективность наукоемких технологий в антикризисном управлении аграрным производством [Текст] / Д.Г. Гвазава, А.Н. Ильченко. - М.: ФГОУ ВПО РГАУ - МСХА им. К.А. Тимирязева, 2005. - 228 с.

3. Смирнова, В.В. Научные предпосылки реализации основных направлений интенсификации полевого кормопроизводства Костромской области [Текст] / В.В. Смирнова // Современные наукоемкие технологии. Региональное приложение. - 2017. - № 1 (49). - С. 122-129.

4. Некрасов, Д.К. Как организовать выращивание высокопродуктивных коров [Текст] / Д.К. Некрасов, Д.Г. Гвазава // Молочное и мясное скотоводство. - 1990. - № 6. - С. 27-31.

\section{References}

1. Gvazava, D.G. Napravlenija povyshenija jeffektivnosti molochnogo skotovodstva v Kostromskoj oblasti [Tekst] / D.G. Gvazava, L.A. Khomutova, L.M. Isaeva // Sovremennye naukoemkie tehnologii. Regional'noe prilozhenie. - 2018. - № 2 (54). - S. 102-112.

2. Gvazava, D.G. Jeffektivnost' naukoemkih tehnologij v antikrizisnom upravlenii agrarnym proizvodstvom [Tekst] / D.G. Gvazava, A.N. Il'chenko. - M.: FGOU VPO RGAU - MSHA im. K.A. Timiryazeva, 2005. - 228 s.

3. Smirnova, V.V. Nauchnye predposylki realizacii osnovnyh napravlenij intensifikacii polevogo kormoproizvodstva Kostromskoj oblasti [Tekst] / V.V. Smirnova // Sovremennye naukoemkie tehnologii. Regional'noe prilozhenie. - 2017. - № 1 (49). - S. 122-129.

4. Nekrasov, D.K. Kak organizovat' vyrashhivanie vysokoproduktivnyh korov [Tekst] / D.K. Nekrasov, D.G. Gvazava // Molochnoe i mjasnoe skotovodstvo. - 1990. - № 6. - S. 27-31. 